Peace-Athabasca Delta. The presentday national and continental significance of the delta is recognized by the decision to build a temporary rock-fill dam (to be finished in December, 1971) in the west arm of the Chenal des Quatre Fourches to impound water from the Birch River and raise water levels in some 60 per cent of the Delta area. The formation of a management advisory board which would coordinate the activities of the many agencies interested in the resources of the area and give an adequate voice to local people is suggested.-G. F. Ledingham, Regina.

\title{
Letters and Notes
}

\section{ALBINO YELLOW-HEADED BLACKBIRD}

At noon on May 22, 1971 I discovered an albino Yellow-headed Blackbird at a roadside slough about a mile east of Moosomin, Saskatchewan. The bird attracted our attention as we were driving by, its startling white plumage making my wife think at first that it was a piece of facial tissue caught on a reed.

There were no other Yellowheads at this shallow marshy place, but a number of Red-winged Blackbirds were nesting nearby. Since I always carry a camera loaded with colour film, I at once proceeded to stalk the bird. Although I was able to approach to within 15 or 20 feet, I regret to say that I was unable to get a photo. Nevertheless, I had a good look at it and made notes of its appearance before leaving the scene.

I contacted Manitoba government wildlife personnel three days after seeing the bird and gave them details of the sighting. Recently I have been urged to make a further record of the observation. The bird, which appeared to be an adult male, lacked the normal black plumage. Except for the usual yellow head and breast it was all white with the exception of a small black spot on the right wing. I was close enough to note that its bill and feet were yellowish in colour instead of black, though of a darker shade of yellow than the head. The head plumage was lightel than that usually observed in this species (a canaryyellow colour). Unfortunately, I was unable to determine the eye colour.
When it flew away, I again noticed that it was white all over except for its yellow head.

I have been informed by $R$. W. Nero that this bird was probably close to a "total albino", that is, almost totally lacking in melanic (black) pigment in its plumage and fleshy parts. (Albinism, it is interesting to note, does not directly affect red or yellow pigments.) It was also suggested that my close approach may have resulted from poor vision in the bird - if it lacked pigment in its eyes. I understand that although albinism is fairly common in members of the blackbird family, there appear to be few reports of albinism in Yellow-headed Blackbirds. - James W. D e mia nyk, 36 Parkville Drive, Winnipeg, Manitoba.

\section{IMPORTANCE OF OCEANS}

The November, 1971 newsletter of the Council of Resource and Environment Ministers explains why the marine environment must be protected. "Photosynthesis within the ocean produces two-thirds of the oxygen consumed by man. Phytoplankton, a major oceanic photosynthesizer, is increasingly threatened and destroyed by pollutants entering waters, principally from dumping. Without phytoplankton there would be no life at sea, and man would suffocate from lack of oxygen and excess of carbon dioxide." According to the Swiss oceanographer, Jacques Piccard, continuation of present levels of ocean dumping could decimate the world's population within the next 50 years. Laws must be introduced to forbid ocean dumping. 


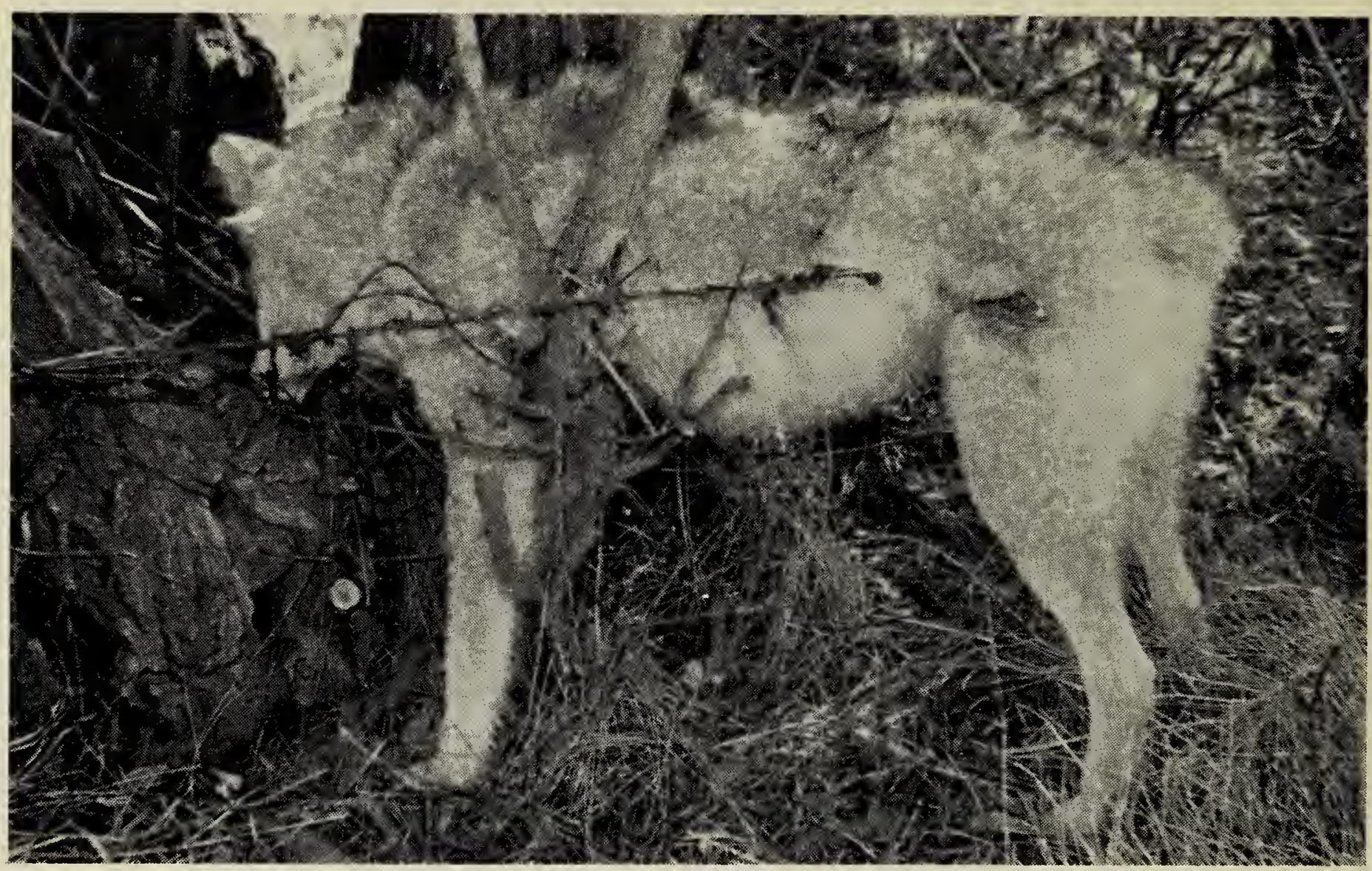

Photo by Sam Alberts, Brooks, Alberta

In reply to the question "How in the World?" (see page 68 in March, 1972 Blue Jay) we have had a number of excellent letters.

Mary K. Anderson, Carlyle, writes on March 14 and suggests: "The coyote was waiting for a mouse, chipmunk or squirrel to emerge from the hole in the partly hollow fallen log. When the intended prey emerged, the coyote reared up high, to pounce with stiff front legs and thus came down very suddenly, and hard between branch and trunk, resulting in a severe blow in the region of the heart and also continued severe pressure on the heart. Result - instant death. The wide stance of the hind legs is correct for a pounce."

E. Kuyt, Canadian Wildlife Service biologist at Fort Smith, N.W.T., would prefer, before offering an opinion, to examine the dead animal, but, based on the information gained from the photo, says: "My guess is that the coyote in chasing prey attempted to jump between the tree and its branch and in doing so impaled itself on a sharp twig, penetrated a vital organ in the chest area and the coyote haemorrhaged internally. Some of the twigs appeared to have been chewed by rabbits or hares and this could explain the existence of the sharp twigs as well as the prey. The coyote may have jumped over the barbed wire or in jumping up with its rear (after having become lodged) flipped its rear legs over the wire. (P.S.) I did not see the coyote's tail in the photograph. The lesion on the animal's left flank could be related to the barb wire. Perhaps the tail is caught by the barb wire?"

In answer to Mr. Kuyt's query about the tail Sam Alberts (who found the coyote and took the photos in April, 1971) wrote in his letter of January 11, 1972, "The coyote was without any sign of a tail, it might have been born that way or at least lost it at a very early age. There was no sign of any stub or a recent scar."

Noticing the absence of the tail : Blue Jay reader from Kindersley (who did not give his name) wrote "It is very plain to see that the coyote committed suicide on the wire fence -imagine a coyote without a fin bushy tail-any self respecting beas 
would do itself in. Seriously, I do believe it was pierced by a piece of the fence. . . and died instantly with only marginal internal bleeding."

Mrs. R. Parfitt, Moosomin, wrote on March 28 that her husband "thinks it was chasing rabbits and ran into a piece of wire which speared its heart." She herself thinks that "it was being chased and that it ran for cover. It died from exhaustion."

Mrs. M. C. Peronne, Clarence, New York on March 28 asks, "How come the tail is missing?" She doubts that the coyote got into the predicament shown in the picture all by itself "because the body is too stiff; if it was instant death surely the body would have slumped and the legs would be bent." She adds: "I am most suspicious. It looks too false, too artificial, too uncanny. Either the coyote was found dead by poisoning or it was chased until dead by snowmobile, then set in this position. All appearances lead me to believe it was a put up job."

Mrs. Peronne concludes her letter by saying that she does not want speculation in the June Blue Jay but that she expects to see a proper analysis following autopsy or postmortem by a competent mammalogist. Unfortunately the analysis she asks for cannot be given because the animal died some 16-18 months ago and we first learned of it when we received the photos and letter from Mr. Alberts five months ago.

Mr. Alberts, Brooks, wrote that there was no evidence that man had placed the animal in this position and poison was ruled out because the nearest poison bait station was 15 miles away. Apparently there was no evidence of fence or sharp branch piercing a vital organ. Mr. Alberts explains: "The coyote appeared to have jumped over the bottom wire of the fence and to have come down with its front feet and mouth in the stump of the willow tree. There was nothing to indicate that it had caught anything and there was no evidence of its having made any struggle to free itself. The body was firmly wedged between a branch and the main trunk of the tree. Possibly the animal came down hard enough to collapse the heart cavity, causing instant death."

\section{ALBINO ROBIN AT SELKIRK, MANITOBA}

During the afternoon of August 13, 1970, Herb Copland of the Manitoba Museum of Man and Nature was notified by Mrs. Kennedy that Mr. and Mrs. Walter Sargent had found a young and apparently abandoned albino robin in their back yard in Selkirk. On his way from Winnipeg to Selkirk, Herb stopped by to pick up my two brothers and me so that we could see this unusual bird.

The robin had pure white plumage except for slightly pinkish feathers on the head, and pink eyes. It was badly infested with lice, but otherwise appeared in good health. It was given to Eric, Jack and me to care for.

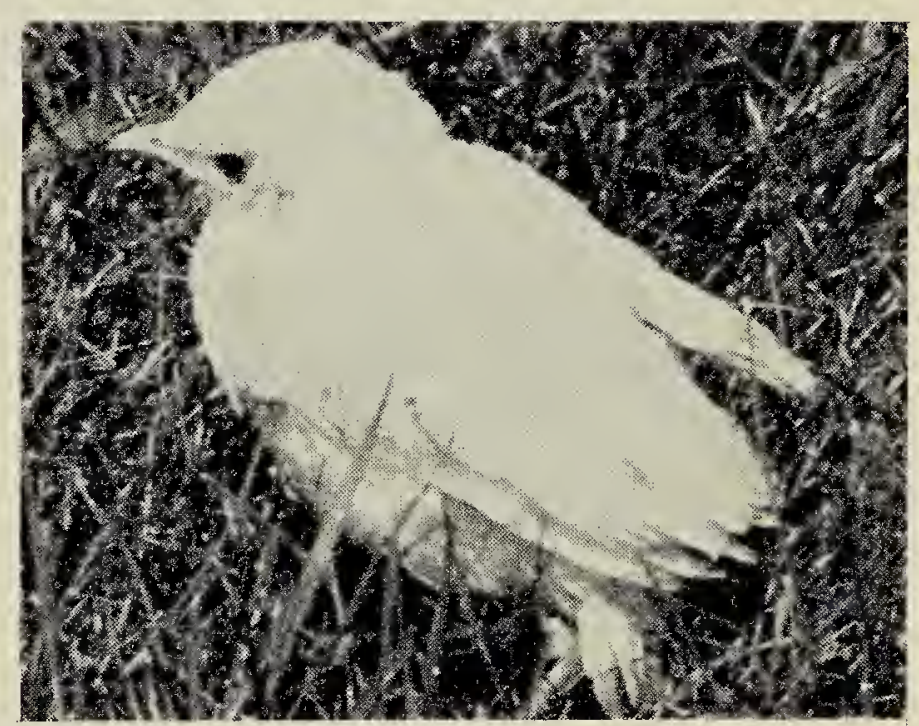

Young albino robin

We solved the lice problem in a couple of days. It took readily to us and ate large amounts of worms, small fruit and other food - and grew as fast as its appetite. After one week, we placed it in an outdoor cage, to become accustomed to its future environment. Unfortunately, the ending was not a happy one - a dog managed to break into the cage. - Norman Lee, R.R. No. 3, Selkirk. 


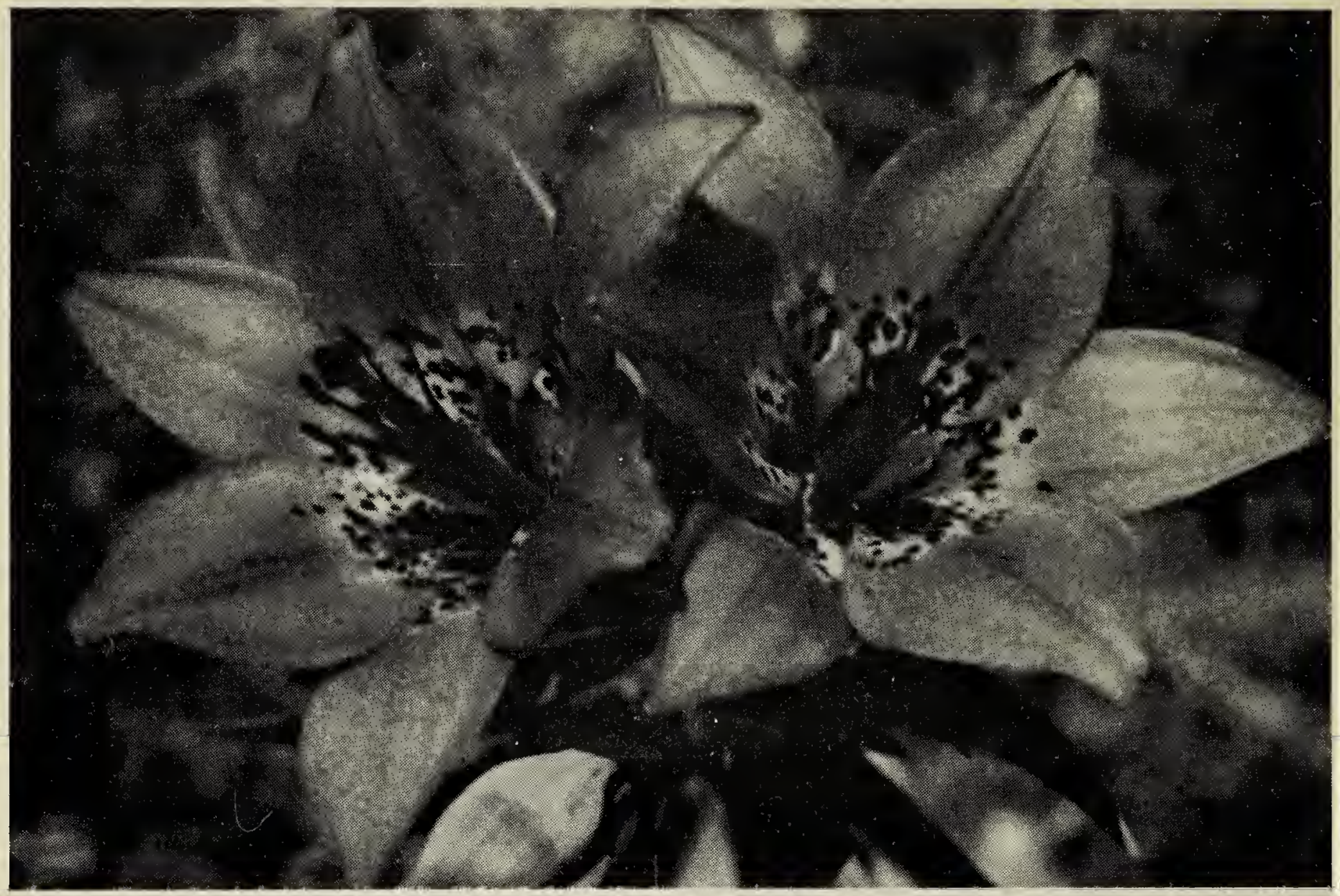

Photo by Helen Morrison, Regina

At this time of year we should all be reminded of what Mrs. R. McLaughlin, writing a year ago in The Yorkton Enterprise, called our "vulnerable emblem." In the past the very existence of this strikingly beautiful lily has been threatened by thoughtless picking and destruction of habitat. All citizens, and particularly Natural History Society members, should attempt to do everything possible to insure that "the flame-like flower" is protected.

\section{OUR LAST FRONTIER}

The Canadian Arctic is one of the last frontiers of the world and in typical fashion man is rushing headlong into making it the kind of place he has made of all other places. This statement is from a Pollution Probe release which asks for support in effecting a fair balance between resource development and the protection both of the environment and of native Canadians in the Arctic. Pollution Probe proposes a five-point program to protect our last frontier. Briefly these proposals include the following:

1. A two-year (or longer) freeze on all new Arctic oil and gas extraction and transportation (pipeline and tanker) and a scaling down of northern exploration activities.

2. Full discussion with Native
People before the commencement of any exploration or development in the Arctic and recognition of the right of Native People to live off the land.

3. Reorganization of the Department of Indian Affairs and Nurthern Development to separate the conflicting interests of development, environment protection and human welfare.

4. Proclamation of the A rctic Waters Pollution Prevention Act and development of regulations to enforce all environment protection acts.

5. The establishment and implementation of official long-range compre. hensive policies regarding the Arctic after information has been made available and public hearings held.

Pollution Probe suggests that citizens write to Prime Minister Trudeau asking him to put a freeze on development in the Arctic unti] 
more is known about how we can protect the Arctic environment. If you want to know more about the problems of the Arctic, write for Pollution Probe's 28-page background statement on the Arctic. Write to Arctic Campaign, Pollution Probe, University of Toronto, Toronto 181, Ontario.

\section{HIGH ARCTIC}

In the March, 1972, Blue Jay there is a review by Margaret Belcher of George Miksch Sutton's book High Arctic. In my library I have a book with the same title, High Arctic, but it was written by Captain R. M. Banks and was published by Dent and Sons, London in 1957. My High Arctic is the story of the British Greenland Expedition of 1952-54, obviously a very different book from the one reviewed in the last issue of the Blue Jay. I wonder if Mr. Sutton had any idea that a book with the same title was in existence? $-C$. S. Williams, Orangeville, Ontario.

\section{MOOSE MOUNTAIN NOTE}

In Birds of Moose Mountain Nero and Lein note Gray Partridge from areas around the park, but none inside. Therefore, I thought it of interest to record that I saw two Gray Partridge on July 3, 1970 inside the park. I think the birds were along the Nature Trail, but all I have recorded is that they were in the park. - Dale Hjertaas, General Delivery, Sub P.O. No. 6, Saskatoon.

\section{CROWS OVERWINTER}

An oddity for Manitoba has occurred. A flock of 37 Common Crows successfully overwintered in 1971-72 near the town of Douglas, Manitoba. Despite an intensely cold and windy December and January the crows did remarkably well. Because of a light snow cover they found ample food in an unharvested millet crop and in sunflower fields. Scavenging at the refuse pit and along the highway also supplied food. Thick willows and poplars near the town provided shelter and a roosting site. - Ray Whaley, Wasagaming, Manitoba.

Editor's Note: An estimated 90 crows wintered at Winnipeg, foraging at refuse dumps and roosting in aspen woods. These are unprecedented numbers for this region. $-R$. $W$. Nero, Department of Mines and Natural Resources, Winnipeg.

\section{ENVIRONMENTAL CHANGE}

Chief Billy Diamond of Rupert House is organizing native resistance to the James Bay Hydro Project which will flood or drain some 144,000 square miles and displace some 5,000 Cree Indians who live in the area. The project will take some 10 years to build, may cost $\$ 10$ billion and holds the promise of 125,000 new jobs during the construction phase alone. Diamond claims that the land belongs to the Cree because the Indians did not sell it, they did not give it away and they were not conquered in battle. - Condensed from James Wilde's report in Time, April 24, 1972.

\section{MASKED SHREW}

In early October, 1971, I found a Masked Shrew, Sorex cinereus, dead in a back alley in Dundurn less than one block from a marshy creek. The specimen was identified by Dr. D. H. Sheppard, Regina. About a year earlier I found a similar animal impaled on a barb of a barbed-wire fence which went through a marsh. These are the only two shrews that I have seen since the winter of 1908-09 at Regina.-E. W. Sullivan, Dundurn, Saskatchewan.

\section{WINDSHIELD STICKER}

When driving around the country we may come in contact with other members of the Saskatchewan Natural History Society and never know it. How about a small bumper or windshield sticker or something in that line to identify members of the society? I am a towerman just north of Meadow Lake Park in the summer. I would like to know how many members of the society I meet in my 
travels. - John S. Rule, Pierceland.

Editor's Note: The society does have a decal of its crest (see back cover) which could be used on a car window. These transparencies are in color and the circle has a diameter of about $3 \frac{1}{2}$ inches. The decals, 35 cents each or three for a dollar may be obtained from the Blue Jay Bookshop, Box 1121, Regina.

\section{INSTITUTE FOR BIRD POPULATION STUDIES}

I am forming an Institute for bird population studies to stress the theoretical and analytical dimensions of the study of bird populations. The institute activities will not overlap with current Nest Record and other such programs but it will attempt to get as much information as possible from Christmas counts and nest record data. It will also try to organize amateur efforts towards cooperative, intensive, single species analyses.

The institute would popularize ornithology and get more people to see the value of bird life. It would analyze data now being gathered and provide an understanding of what regulates bird numbers. No one can presently predict fluctuations in any non-game North American bird population. I am personally committed to enhancing and protecting bird life in our environment. If you agree, I hope you will become a member of the Institute. More information later. Steve Fretwell, Biology, Kansas State University, M a n h t t a n, Kansas, 66502.

\section{THE NATURE CONSERVANCY OF CANADA}

The Nature Conservancy of Canada is a charitable organization formed to acquire and preserve natural land areas throughout Canada for the benefit of future generations.

The Conservancy held its annual meeting April 15, 1972, in Toronto when it reviewed its accomplishments since its foundation in 1963 and considered its present financial position and its role in the future. In 1970 the Conservancy had realized that to adequately fill its role it must have a full-time Executive Director and an Administrative Director. Mr. Aird Lewis and Mr. Charles Sauriol respectively occupy these positions and 1971 has witnessed a rapidly expanding programme.

During 1971 (the first year with two full-time employees), the size and the complexity of projects considered by the Conservancy have increased tremendously and the annual meeting of the Board of Trustees reflected considerable satisfaction in the progress made in the preservation of natural areas at the same time as it expressed the need to acquire more money and save other natural areas.

To date, seven projects have been completed and there are at least twice as many projects which are actively being studied. It is, of course, important that each area be carefully studied before funds are spent for land acquisition. Sites acquired by Nature Conservancy will be transferred to a local conservation organization where the local group is able and willing to assume legal responsibility. The transfer title will have the rider that, if the local group disbands or is unable to operate, the title then returns to Nature Conservancy of Canada. The objective of this rider is simply to guarantee longterm protection to the natural values of the property.

Since the organization developed in Ontario (because of the need to preserve one particular property there), a number of the projects preserved or being considered by the Conservancy are in Ontario. The Nature Conservancy of Canada, however, is a truly national organization which is prepared to consider areas in all parts of Canada. Projects mentioned above include three in Nova Scotia and one each in Quebec, Alberta and British Columbia. No specific area in Saskatchewan is as yet being considered by the Conserv- 
ancy.

This year, 1972, both Mr. Lewis and Mr. Sauriol will visit Saskatchewan to meet conservationists and natural history people and to examine some of the properties which need to be saved. At that time we will also approach Corporations and individuals who wish to donate money or property to be used for long-term preservation of natural areas. If you know of natural areas which should be preserved or which are in imminent danger of being destroyed, please write to me about them and if you wish to receive more information about Nature Conservancy of Canada, write to Mr. Aird Lewis, 120 Eglinton Ave. E., Toronto 12, Ontario - G. F. Ledingham, 2335 Athol St., Regina.

\section{APOLOGY}

THE GOOD, GOOD EAR'SH. 1971. By Ralph O. Brinkhurst and Donald A. Chant. The MacMillan Co. of Canada, Ltd., Toronto. $\$ 6.95$; paper $\$ 3.95$.

This book was reviewed by R. D. Symons, Silton, in the March issue of the Blue Jay but somehow we neglected to include the names of the authors. Our apologies go to Brinkhurst and Chant and also to the publisher and the reviewer.

\section{CORRECTION}

On December 21, 1971, E. Kuyt, Wildlife Biologist, Canadian Wildlife Service, Fort Smith, wrote to point out that the Ruffed Grouse shown on page 18, March Blue Jay, 1971 was misidentified as Spruce Grouse. A previous letter pointing out our error is printed in the June, 1971, Blue Jay. The editor welcomes corrections from members if errors occur in the Blue Jay.

\section{ALBINO REDPOLL}

Among the many redpolls that fed at our feeding station this past winter was an albino. The wings and tail were pure white, the body had a creamy tinge when seen against the white snow, the chest had just the faintest streaks of grey and the front of the head had the red cap as all redpolls do (it was very cute when seen close up). - S. O. Jordheim, White Bear, Saskatchewan.

\section{BAN ON POISONS}

The March 22, 1922 news release from the United States Department of the Interior announces that the use of poisons for the control of predatory animals has been banned on all federally-owned lands in the United States. The Fish and Wildlife Service and state, local and private co-operators may control the coyote and other predators by trapping, shooting and denning. Poisons as a means of predator control can only be used if a special permit has been obtained to cover a specified situation. The release also states that there will be an expanded federal research effort to learn more about the control and conservation of predatory animals.

\section{BIRD PROTECTION}

Recent amendments to the wildlife convention between the United States and Mexico give extra protection, especially from wanton shooting, to 32 additional families of birds. These amendments increase the number of protected families from 31 to 63 . Six of the families comprise all the birds of prey, including ospreys and vultures. Since the list of protected birds includes crows, magpies and horned owls, there are provisions for population control in certain nuisance situations.

Because only 11 of the 32 families are currently protected by the 1916 Migratory Bird Treaty between the United States and Canada, it is obvious that Canada's agreements with the United States should now be updated.

\section{MAN AND THE BIOSPHERE}

The International Coordinating Council for MAB met, November 
$9-19,1971$, and agreed to a problem oriented programme made up of 13 projects. The general objectives are: "to develop the basis within the natural and social sciences for the rational use and conservation of the resources of the biosphere and for the improvement of the global relationship between man and the environment; to predict the consequences of today's actions on tomorrow's world, and thereby to increase man's ability to manage efficiently the natural resources of the biosphere."

One project, "The conservation of populations of plants and animals and the genetic variation they represent," supports the work of the International Union for the Conservation of Nature which this year meets September 10-16 at Banff, Alberta.

\section{POSSIBLE RECENT KIT FOX RECORD IN SASKATCHEWAN}

In reply to an inquiry from the Blue Jay editor, Dr. J. Looman, Phytosociologist, Forage Production and Utilization, Research Station, Swift Current wrote:

"I found the Kit Fox along the roadside between sections 13 and 24, Twp. 7, Rge. 15, W3rd, on May 27, 1969. I stopped and examined the carcass with an eye on the possibility that it might still be suitable for mounting. However, the animal had been dead for too long and the skin had dried out and hardened.

"Measurements on the carcass were: body length 27 inches, tail $91 / 2$ inches; and sex - male. My conclusion that it was a Kit Fox is based on its overall size, which is very small, but in particular on the size and shape of its ears. These measured almost four inches and were almost round. It was this fact that made me stop.

"In addition, I also was already fairly sure that I'd seen Kit Foxes in Twp. 6, Rge. 15, in the Beaver Valley Community Pasture."
Editor's Note: May I ask the mammalogists of the society if the evidence given by J. Looman is acceptable? The last authentic report of the Kit Fox in Saskatchewan is of an animal trapped in 1927 near Ravenscrag and donated to the Museum in Regina where it is mounted and preserved (Blue Jay 14:63-65, 1956). More recently, David Chandler (Blue Jay $23: 135$, 1965) reports hearing, near Shaunavon in 1964, and near Masefield back in the 1950's what he believes to be the call of the Kit Fox. Can any of our researchers supply reports? Are there still some Kit Fox in Saskatchewan?

\section{WHOOPING CRANE CONSERVATION ASSOCIATION}

This international association meets in Regina at the Museum of Natural History, September 18-20, 1972. Registration and programme information may be obtained from $\mathrm{Mr}$. $\mathrm{M}$. K. Baker, Director of the Museum or Mr. E. L. Paynter, 2175 Retallack Street, Regina.

\section{SNHS ANNUAL MEETING}

At the annual meeting in the Museum of Natural History, Regina, October 13, 14, 1972, Dr. Douglas Pimlott, President of the Canadian Nature Federation will be the guest speaker. He will talk about the role of naturalists in the environmental affairs of Canada.

\section{LATE MAILING}

The June, 1972 Blue Jay has been delayed by a printers' strike in Regina. We regret any inconvenience that this may have caused members of the society. In spite of the lateness of this mailing (early July instead of early June) we hope that the September Blue Jay will be produced on schedule. Please submit material for the September issue immediately. 